\title{
Iron reduction by the deep-sea bacterium Shewanella profunda LT13a under subsurface pressure and temperature conditions
}

\author{
Aude Picard ${ }^{1,2,3}$ *, Denis Testemale ${ }^{4,5}$, Laura Wagenknecht ${ }^{1}$, Rachael Hazael $^{6}$ and Isabelle Daniel ${ }^{7}$ \\ ' Department of Biogeochemistry, Max Planck Institute for Marine Microbiology, Bremen, Germany \\ ${ }^{2}$ MARUM Center for Marine Environmental Sciences, Bremen, Germany \\ ${ }^{3}$ Center for Applied Geoscience, Eberhard Karls University Tübingen, Tübingen, Germany \\ ${ }^{4}$ Institut Néel, Université Grenoble Alpes, Grenoble, France \\ ${ }^{5}$ Institut Néel, Centre National de la Recherche Scientifique, Grenoble, France \\ ${ }^{6}$ Christopher Ingold Laboratory, Department of Chemistry, University College London, London, UK \\ ${ }^{7}$ CNRS, Laboratoire de Géologie de Lyon, Ecole Normale Supérieure de Lyon, Université Claude Bernard Lyon 1-Université de Lyon, UMR5276, Lyon, France
}

\section{Edited by:}

D'Arcy Renee Meyer-Dombard, University of Illinois at Chicago, USA

\section{Reviewed by:}

Federico Lauro, University of New South Wales, Australia

Jinjun Kan, Stroud Water Research Center, USA

Cristina Takacs-Vesbach, University of New Mexico, USA

\section{${ }^{*}$ Correspondence and present} address:

Aude Picard, Organismic and Evolutionary Biology, Harvard University, 16 Divinity Avenue, Cambridge, MA 02138, USA e-mail: apicard@fas.harvard.edu; audeameliepicard@gmail.com
Microorganisms influence biogeochemical cycles from the surface down to the depths of the continental rocks and oceanic basaltic crust. Due to the poor recovery of microbial isolates from the deep subsurface, the influence of physical environmental parameters, such as pressure and temperature, on the physiology and metabolic potential of subsurface inhabitants is not well constrained. We evaluated Fe(III) reduction rates (FeRRs) and viability, measured as colony-forming ability, of the deep-sea piezophilic bacterium Shewanella profunda LT13a over a range of pressures $(0-125 \mathrm{MPa})$ and temperatures $\left(4-37^{\circ} \mathrm{C}\right)$ that included the in situ habitat of the bacterium isolated from deep-sea sediments at $4500 \mathrm{~m}$ depth below sea level. S. profunda LT13a was active at all temperatures investigated and at pressures up to $120 \mathrm{MPa}$ at $30^{\circ} \mathrm{C}$, suggesting that it is well adapted to deep-sea and deep sedimentary environments. Average initial cellular FeRRs only slightly decreased with increasing pressure until activity stopped, suggesting that the respiratory chain was not immediately affected upon the application of pressure. We hypothesize that, as pressure increases, the increased energy demand for cell maintenance is not fulfilled, thus leading to a decrease in viability. This study opens up perspectives about energy requirements of cells in the deep subsurface.

\section{Keywords: Fe reduction, pressure, Shewanella profunda, temperature, XANES}

\section{INTRODUCTION}

Less than $1 \%$ of microorganisms of the environment have been isolated in pure cultures (Amann et al., 1995). This trend is even more pronounced for microorganisms living in the deep subsurface (D'Hondt et al., 2004; Parkes etal., 2009; Colwell and D'Hondt, 2013). For example, only a few tens of microorganisms have been isolated from deep subseafloor sediments (Mikucki etal., 2003; Biddle etal., 2006; Batzke etal., 2007). Therefore very little is known about the physiology of subsurface microorganisms. Pressure is a unique parameter of deep subsurface environments and increases at a rate of 10,15 , and $28 \mathrm{MPa} \mathrm{km}^{-1}$ in the water column, sediments and continental, and oceanic rocks, respectively. Piezophilic (i.e., pressure-adapted) microorganisms have their highest growth rate at pressures $>0.1 \mathrm{MPa}$ (Yayanos, 1995). Piezophilic bacteria and archaea have been isolated from seawater, subseafloor sediments, deep-sea animals, and wood fall (see review by Fang etal., 2010, for the most recent list of piezophilic microorganisms). The comparison between piezophilic and piezo-sensitive microorganisms has revealed physiological and molecular adaptations to life under pressure (Simonato et al., 2006; Lauro and Bartlett, 2007), such as a unique membrane composition of piezophilic bacteria (DeLong and Yayanos, 1985), an increase in certain amino acids in proteins of piezophilic archaea (Di Giulio, 2005) or pressure-regulated gene expression in some deep-sea bacteria (Bartlett et al., 1995; Nakasone et al., 1998).

Pressure and temperature have significant impact on microbial activity. Only a few anaerobic processes affecting biogeochemical cycles of the deep subsurface have been studied under pressure (Picard and Daniel, 2013, and references therein). Among those, sulfate reduction, which is the most important process in sedimentary subseafloor environments, is generally enhanced at in situ pressure (Kallmeyer and Boetius, 2004; Bowles et al., 2011; Vossmeyer et al., 2012). Although Fe(III) reduction is important in deep environments (Lovley and Chapelle, 1995), the effects of pressure and temperature on $\mathrm{Fe}(\mathrm{III})$ reduction have hardly been investigated. We previously showed that the bacterium Shewanella oneidensis MR-1 can proceed with $\mathrm{Fe}(\mathrm{III})$ reduction up to pressures of $\sim 110 \mathrm{MPa}$ (Picard et al., 2012). While MR-1 is a piezosensitive strain, $\mathrm{Fe}(\mathrm{III})$ reduction rates (FeRRs) were increased in the range of 30-50 MPa (Picard et al., 2012). In S. piezotolerans WP3, FeRR, and magnetite production decreased with increasing pressure, concomitantly with an increase in crystallinity and grain size of magnetite (Wu et al., 2013). 
In this study we investigated the effects of temperature and pressure on the FeRR and viability of S. profunda LT13a. The Shewanella group is appropriate to study the effects of pressure and temperature on metabolic processes as it includes species adapted to a variety of pressure and temperature regimes (Kato and Nogi, 2001). Moreover Shewanella is ubiquitous in the environment, making it a relevant model for environmental studies (Fredrickson et al., 2008). Finally Shewanella are metabolically diverse and several species of Shewanella have the ability to reduce $\mathrm{Fe}$ (III), allowing comparison of rates between species under similar conditions (Venkateswaran et al., 1999; Kato and Nogi, 2001). We show here that $S$. profunda LT13a is metabolically active over a large range of pressures $(0-110 \mathrm{MPa})$ and temperatures (4$37^{\circ} \mathrm{C}$ ). At high pressures (HPs), the respiratory chain does not seem immediately affected by pressure. We hypothesize that the increase in energy demand with pressure leads to a loss in viability and thus to an arrest of activity.

\section{MATERIAL AND METHODS BACTERIAL STRAIN AND CULTURE CONDITIONS}

Shewanella profunda LT13a (named hereafter Sp LT13a) was purchased from the DSMZ collection (strain DSM 15900). Sp LT13a is a piezophilic and mesophilic bacterium isolated from deep-sea sediments, with optimal pressure and temperature for growth at $10 \mathrm{MPa}$ and $30^{\circ} \mathrm{C}$, respectively (Toffin et al., 2004). Sp LT13a has the ability to use Fe(III) as an electron acceptor (Toffin et al., 2004). Sp LT13a was grown aerobically in yeast extract-peptone (YP) medium at $30^{\circ} \mathrm{C}$ (shaking $160 \mathrm{rpm}$ ) to produce biomass and harvested after $\sim 15 \mathrm{~h}$ in early stationary phase, washed with saline solution and kept on ice until used. For iron reduction experiments, the minimal medium M1 was used (Kostka and Nealson, 1998) and supplemented with $2 \mathrm{gl}^{-1}$ tryptone and $0.2 \mathrm{gl}^{-1}$ yeast extract to provide electron donors and carbon sources. Fe(III)citrate was prepared as previously described (Kostka and Nealson, 1998) and added to the medium at a final concentration of 3 and $5 \mathrm{mM}$, for pressure and temperature experiments, respectively. Sp LT13a was inoculated in M1 medium at initial CFU concentrations of $\sim 10^{8}$ cells $\mathrm{ml}^{-1}$ for temperature experiments and of $\sim 10^{8}$ and $\sim 10^{9}$ cells $\mathrm{ml}^{-1}$ for pressure experiments, then the inoculated medium was distributed to incubation vessels (see below). In our study, a high-density inoculum was used to obtain the most from the limited amount of beamtime available at the synchrotron (see subsection on in situ pressure experiments) and to study the effects of pressure on initial FeRR without significant variations of the cell density at the beginning of the experiments. The use of high-density inocula is also typical of iron reduction experiments (Roden and Zachara, 1996; Roden, 2006).

$\mathrm{Fe}(\mathrm{III})$ reduction at atmospheric pressure was investigated at 4 , $10,20,30$, and $37^{\circ} \mathrm{C}$, in a series of mini hungate tubes closed with stoppers and plastic screw caps. All mini hungate tubes are thus individual experiments started from the same cell suspension. At each time point, one mini hungate tube was taken and its content was used for $\mathrm{Fe}(\mathrm{II})$ measurements using the ferrozine assay (Stookey, 1970) and for colony-forming unit (CFU) counts. For pressure incubations at $30^{\circ} \mathrm{C}$, cultures were inoculated in serum bottles closed with rubber septa and sealed with aluminum caps then transferred to containers that fit in the two different pressure vessels used for these experiments (see next sub-sections). For each pressure experiment, the leftover culture was incubated at atmospheric pressure in the serum bottle as a control. Headspace in hungate tubes and serum bottles was flushed with $\mathrm{N}_{2}$ to ensure anoxic conditions. Abiotic controls were performed using medium without cells.

\section{EX SITU PRESSURE EXPERIMENTS (10-50 MPa)}

Cultures were transferred from serum bottles to sterile plastic syringes that were sealed with a needle inserted in a rubber stopper after removing the headspace. All syringes represent individual experiments started from the same cell suspension. Syringes were incubated in HP cylinders similar to those described by Zobell and Oppenheimer (1950). Pressure was transmitted to the culture via the syringe piston in a HP cylinder filled with water as pressuretransmitting medium, pressurized using a multi-fluid hand pump $\left(\mathrm{MP}-1000\right.$, Enerpac $\left.{ }^{\mathrm{TM}}\right)$. The maximal pressure achieved in the HP cylinders was $50 \mathrm{MPa}$. HP cylinders filled with water were stored and pre-incubated at $30^{\circ} \mathrm{C}$ to minimize pressure changes. Several syringes were incubated in each HP cylinder. At each sampling time, the HP cylinders were decompressed to recover one syringe then recompressed. Similarly to the ambient pressure experiments, the content of the syringes was used for $\mathrm{Fe}(\mathrm{II})$ measurements and CFU counts.

\section{IN SITU PRESSURE EXPERIMENTS (10-125 MPa)}

To avoid decompression at each sampling time, we employed an experimental setup that enables in situ monitoring of Fe oxidation state and speciation in microbial cultures in an optimized pressure incubation system (autoclave) using X-ray absorption spectroscopy. The feasibility of this method was validated in a previous work (Picard et al., 2011). The experimental setup used in this study is the same as the one used for the study of Fe(III) reduction under pressure by S. oneidensis MR-1 (Picard et al., 2012). For each pressure experiment, a culture was prepared as described above and transferred from a serum bottle to the sample container, which is a glass-like carbon tube closed at both ends by free pistons. The glass-like carbon tube was then quickly transported to the beamline and placed inside the autoclave, which is aligned within the X-ray beam path and in front of detectors (Testemale et al., 2005). The autoclave that was thermalized at $30^{\circ} \mathrm{C}$ through the duration of all experiments was then pressurized to a given pressure between 10 and $125 \mathrm{MPa}$. The HP windows of the autoclave were made of $0.5 \mathrm{~mm}$ glass-like carbon for entrance and exit ports and of $4.5 \mathrm{~mm}$ Be for the fluorescence port, to maximize the signal at the low X-ray energy of the Fe absorption edge $(7112 \mathrm{eV})$. The Fe oxidation state was monitored in situ in the autoclave without decompression by acquiring at regular time intervals X-ray absorption near-edge structure (XANES) spectra at the Fe K-edge. The culture was decompressed only at the end of the experiments and was recovered for CFU counts. With this experimental setup, only one experiment can be performed at a time. The use of high-density inoculum allowed us to optimize the number of experiments during the allocated beamtime and perform experiments at 10,60, and $80 \mathrm{MPa}$ during a first session and at 10,40,70,110, $125 \mathrm{MPa}$ during a second 
session. Only the 10-MPa experiment was duplicated. After filling the glass-like carbon tube, the culture left in the serum bottle was incubated at $30^{\circ} \mathrm{C}$ and atmospheric pressure and served as a control to ensure that the strain behaved similarly (i) from one experiment to another and (ii) from one experimental session at the synchrotron to another and (iii) and that the changes observed in $\mathrm{Fe}$ (II) production were caused by the sole pressure parameter. Abiotic controls consisted of medium free of cells incubated at $30^{\circ} \mathrm{C}$ and atmospheric pressure within which the $\mathrm{Fe}$ oxidation state was monitored with similar acquisition parameters. No photoreduction of $\mathrm{Fe}(\mathrm{III})$ occurred under the X-ray beam.

\section{FERROZINE ASSAY}

Samples $(100 \mu \mathrm{l})$ were acidified in $900 \mu \mathrm{l} 0.5 \mathrm{M} \mathrm{HCl}$ and $\mathrm{Fe}^{2+}$ was quantified using the ferrozine assay (Stookey, 1970).

\section{X-RAY ABSORPTION NEAR-EDGE STRUCTURE SPECTROSCOPY AND DATA ANALYSIS}

X-ray absorption near-edge structure spectroscopy was performed at the FAME beamline of the European Synchrotron Radiation Facility (Grenoble, France) during two experiments for a total of 10 days (6 days allocated in 2010 and 4 days allocated in 2012). The optical characteristics of the beamline are described elsewhere (Proux et al., 2005, 2006). XANES spectra were acquired at the Fe K-edge at regular time intervals in the autoclave. Details on the acquisition parameters are available in Picard et al. (2012). XANES spectra were processed and analyzed using the Horae Athena software (Ravel and Newville, 2005). Each XANES spectrum was normalized and fitted to a linear combination of $\mathrm{Fe}$ (II) and $\mathrm{Fe}$ (III) standard spectra as measured in solutions of Fe(II) sulfate and $\mathrm{Fe}$ (III) citrate, respectively, using a least-square minimization procedure. From the relative contribution of $\mathrm{Fe}$ (II) and $\mathrm{Fe}$ (III) at each time point and from the known initial concentration of $\mathrm{Fe}$ (III) in the medium, we could calculate Fe(II) concentrations as a function of time.

\section{COLONY-FORMING UNIT COUNTING}

The CFU assay was used to estimate the number of viable cells at the end of in situ experiments, at each sampling point during ex situ experiments, as well as on controls of the in situ experiments. $100 \mu \mathrm{l}$ of culture was serially diluted in saline solution $(\mathrm{NaCl}$ $0.9 \%$ ) and 4 drops of $10 \mu \mathrm{l}$ from each dilution were deposited on solid M1 medium containing Fe(III)-citrate. Colonies were counted after 2 days of incubation at $30^{\circ} \mathrm{C}$. Culture samples from the autoclave were plated after $12 \mathrm{~h}$ to allow for recovery.

\section{KINETIC MODEL}

Similarly to our previous study on the effects of pressure on FeRR by $S$. oneidensis MR-1 model (Picard et al., 2012), the data were always fitted by a first-order kinetic model:

$$
\mathrm{Fe}(\mathrm{II})_{t}=\mathrm{Fe}(\mathrm{II})_{\max }\left(1-\mathrm{e}^{-k t}\right)
$$

where $\mathrm{Fe}(\mathrm{II})_{t}$ is the concentration of $\mathrm{Fe}(\mathrm{II})$ in $\mathrm{mM}$ at time $t$, $\mathrm{Fe}(\mathrm{II})_{\max }$ is the final concentration of $\mathrm{Fe}(\mathrm{II})$ produced [equivalent to the maximal amount of $\mathrm{Fe}$ (III) reduced] in $\mathrm{mM}, k$ is the first-order rate coefficient in $\mathrm{h}^{-1}$ and $t$ is the time in $\mathrm{h}$. Initial
FeRRs in $\mathrm{mM} \mathrm{h}^{-1}$, referred to as FeRR were calculated at $t=0$. Average cellular FeRR were calculated for Sp LT13a, for S. oneidensis MR-1 based on our previous study (Picard et al., 2012) and unpublished results, and recalculated for S. piezotolerans WP3 (Wu et al., 2013) by dividing initial FeRR by initial CFU concentrations.

\section{RESULTS}

\section{EFFECTS OF TEMPERATURE ON IRON REDUCTION}

The temperature range for growth of $S p$ LT13a is $4-37^{\circ} \mathrm{C}$ (Toffin et al., 2004). We investigated the effects of temperature on iron reduction by strain $\mathrm{LT} 13 \mathrm{a}$ at $4,10,20,30$, and $37^{\circ} \mathrm{C}$ at atmospheric pressure (Figure 1). At all temperatures $\mathrm{Fe}(\mathrm{III})$ reduction started immediately after the beginning of the experiments and $\mathrm{Fe}$ (II) production reached a plateau (Figure 1A). At 20, 30, and $37^{\circ} \mathrm{C}$, CFU concentrations were stable or slightly oscillating until just before Fe(II) reached a plateau, after 100,60 , and 25 h, respectively, then dropped to $10^{6}, 10^{5}$, and $10^{3} \mathrm{CFU} \mathrm{ml} \mathrm{m}^{-1}$, respectively (Figure 1B). After 180, 150, and 100 h, respectively, CFU concentrations increased again to reach $10^{5}-10^{6} \mathrm{CFU} \mathrm{ml}^{-1}$ (Figure 1B). At 4 and $10^{\circ} \mathrm{C}$, CFU concentrations oscillated as a function of time but never fell below $10^{6} \mathrm{CFU} \mathrm{ml}^{-1}$. At $4,10,20$, and $30^{\circ} \mathrm{C}$, almost all $\mathrm{Fe}$ (III) provided was reduced, i.e., 91, 96, 88, and 92\%, respectively (Figure 1C, green bars, left axis). The amount of $\mathrm{Fe}$ (III) reduced at $37^{\circ} \mathrm{C}$ decreased to $40 \%$ of the total $\mathrm{Fe}$ (III) provided (Figure 1C, green bars, left axis). FeRR increased linearly with temperature between 4 and $37^{\circ} \mathrm{C}$ (Figure 1C, black triangles, right axis). Although the highest initial rate at $37^{\circ} \mathrm{C}$ was almost twice as high as the rate at $30^{\circ} \mathrm{C}$, the cells stopped reducing $\mathrm{Fe}$ (III) after $25 \mathrm{~h}$. A linear regression analysis of the FeRR plotted according to the Arrhenius equation allowed to calculate an activation energy of $50.3 \pm 0.8 \mathrm{~kJ} \mathrm{~mol}^{-1}$ for $\mathrm{Fe}(\mathrm{III})$ reduction (data not shown).

\section{EFFECTS OF PRESSURE ON IRON REDUCTION}

Shewanella profunda LT13a grows in the range 0-50 MPa (Toffin et al., 2004). In this study we used initial CFU concentrations of

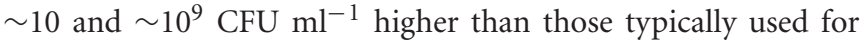
growth experiments. We could thus evaluate the effect of pressure on initial FeRR without variation of cell concentration during the first stage of incubations. At atmospheric pressure, initial FeRR increased with initial CFU concentration (Figure 2). At similar initial CFU concentrations, FeRR were lower when $3 \mathrm{mM} \mathrm{Fe}$ (III) was provided as initial electron acceptor concentration than when $5 \mathrm{mM} \mathrm{Fe}$ (III) was provided (Figure 2).

Figure 3A displays the $\mathrm{Fe}(\mathrm{II})$ production as a function of time in cultures inoculated with $\sim 10^{8} \mathrm{CFU} \mathrm{ml}{ }^{-1}$. Between 0.1 and $40 \mathrm{MPa}$, no delay was observed in the production of $\mathrm{Fe}(\mathrm{II})$, while initial $\mathrm{Fe}(\mathrm{II})$ production was very limited at $50 \mathrm{MPa}$. Over the first $20 \mathrm{~h}, \mathrm{CFU}$ were stable at $0.1,20$, and $30 \mathrm{MPa}$, increased at $10 \mathrm{MPa}$ and decreased at $40 \mathrm{MPa}$ (Figure 3B). At $50 \mathrm{MPa}$, no CFU could be counted after the start of the experiment. Cells reduced $60 \%$ of $\mathrm{Fe}$ (III) provided at $0.1,10$, and $20 \mathrm{MPa}, 19,9$, and $3 \%$ at 30,40 , and $50 \mathrm{MPa}$, respectively (Figure 3C, orange bars, left axis). FeRR were the highest at $10 \mathrm{MPa}$ and then decreased with increasing pressure (Figure 3C, black triangles, right axis). A linear fit to the iron reduction yield between 10 and $50 \mathrm{MPa}$ (not shown) indicated that $S p$ LT13a cells stopped reducing Fe(III) at $53 \pm 2 \mathrm{MPa}$. 


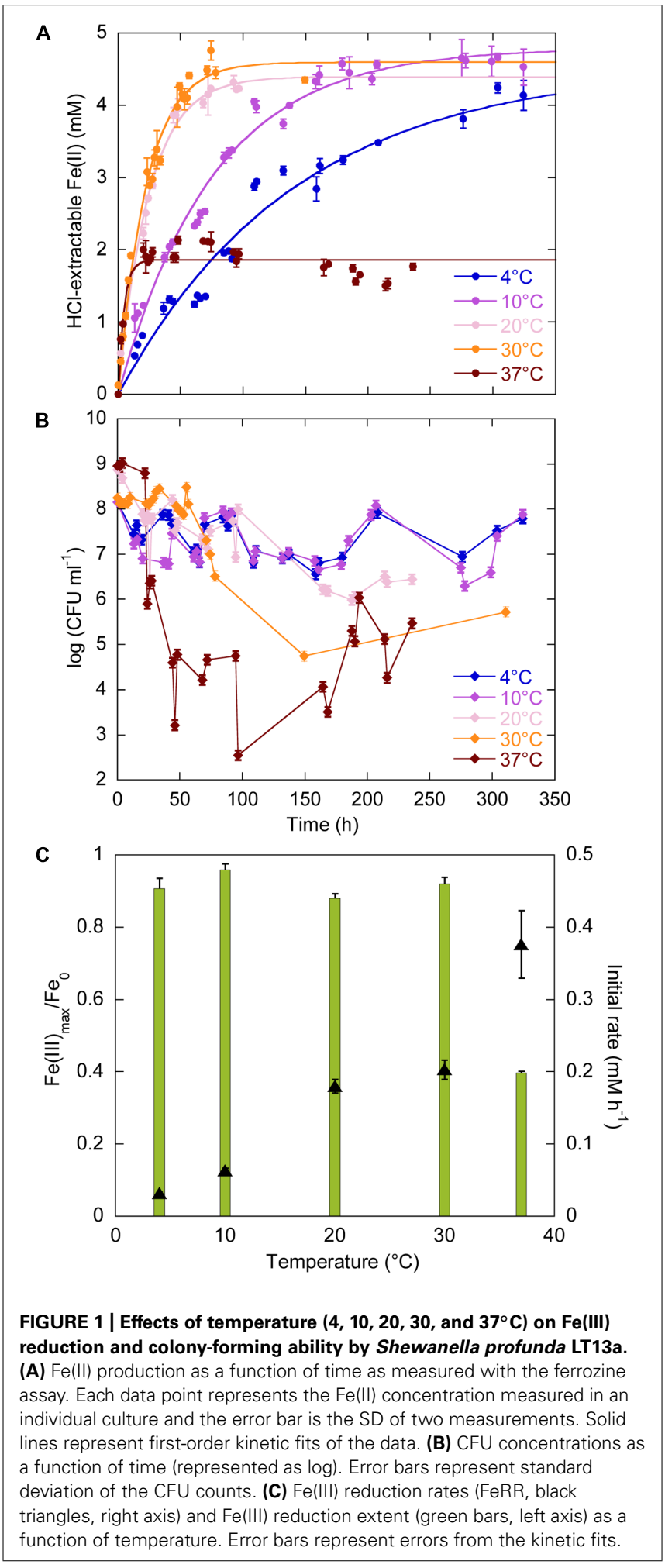

In experiments starting with the highest CFU concentration $10^{9} \mathrm{CFU} \mathrm{ml}^{-1}$, we did not observe any delay in $\mathrm{Fe}(\mathrm{II})$ production between 0.1 and $110 \mathrm{MPa}$ (Figure 4A). At $125 \mathrm{MPa}$, no Fe(III) was reduced anymore. Up to $40 \mathrm{MPa}, \mathrm{CFU}$ concentrations at the end of experiments were close to the initial ones, whilst CFU

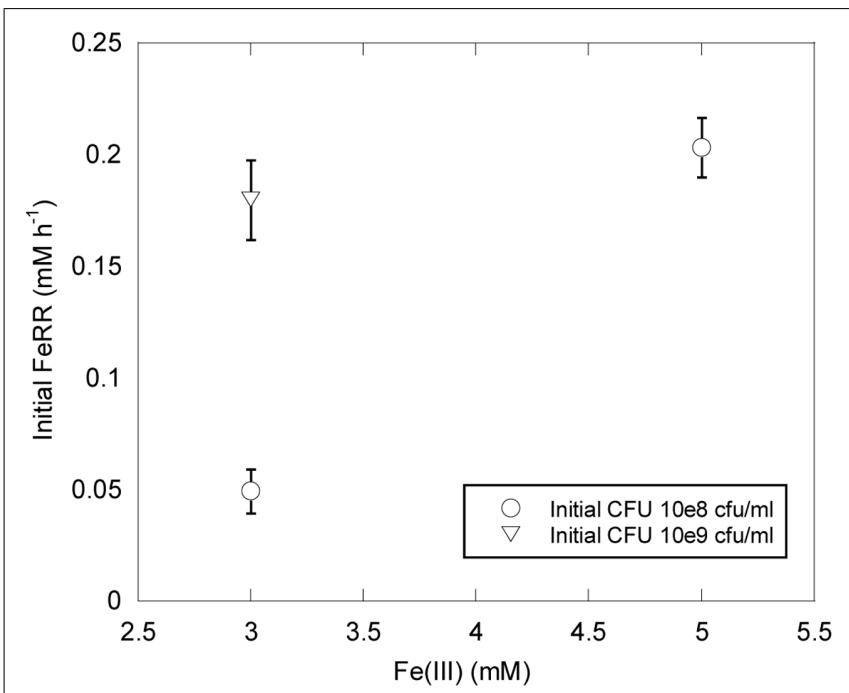

FIGURE 2 | Effects of Fe(III) concentration and initial CFU on FeRR at atmospheric pressure and $30^{\circ} \mathbf{C}$. Error bars represent errors from kinetic fits.

concentrations decreased between 60 and $80 \mathrm{MPa}$ (Figure 4B). At the end of the experiments at 70 and $100 \mathrm{MPa}$, there were no CFU forming anymore. Unfortunately, the culture incubated at $125 \mathrm{MPa}$ was lost during the decompression of the autoclave, as it occurs sometimes when helium that serves as pressure medium does not exsolve fast enough from either the medium or the seals. Cells reduced $88 \%$ of the $\mathrm{Fe}(\mathrm{III})$ provided at atmospheric pressure (Figure 4C, yellow bars, left axis). The highest amount of Fe(III) reduced was $90 \%$ at $10 \mathrm{MPa}$. This amount decreased progressively with increasing pressure. At $110 \mathrm{MPa}$, cells still reduced $18 \%$ of the $\mathrm{Fe}$ (III) provided. FeRR were highest between 10 and $40 \mathrm{MPa}$ then decreased as pressure increased. A linear fit to the data between 40 and $100 \mathrm{MPa}$ (not shown) estimated the arrest of activity at $120 \pm 5 \mathrm{MPa}$, in good agreement with the experiment at $125 \mathrm{MPa}$ that did not show any activity.

\section{AVERAGE CELLULAR FE(III) RESPIRATION RATES UNDER PRESSURE}

We evaluated the effects of pressure on average initial FeRR per CFU in Sp LT13a (Figure 5). All values fell in the same range, independently of the initial CFU concentration. A linear regression analysis of the cellular FeRR showed only a slight decrease as a function of pressure. We compared these results with average cellular FeRR of $S$. oneidensis MR-1, based on our previous study (Picard et al., 2012) and of S. piezotolerans WP3 (Wu et al., 2013). Average cellular FeRR were higher in S. oneidensis MR-1 than in S. profunda LT-13. S. piezotolerans WP3 fell between both strains. Cellular FeRR decreased at the same rate for both deepsea strains while these were stable over the $P$ range of activity in MR-1.

\section{DISCUSSION}

\section{CELL DENSITY AFFECTS P RANGES OF ACTIVITY AND SURVIVAL}

At ambient pressure, FeRR increased with increasing initial CFU concentration (Figure 2), as seen in other studies with $S$. alga BrY (Roden and Zachara, 1996) and Geobacter sulfurreducens 


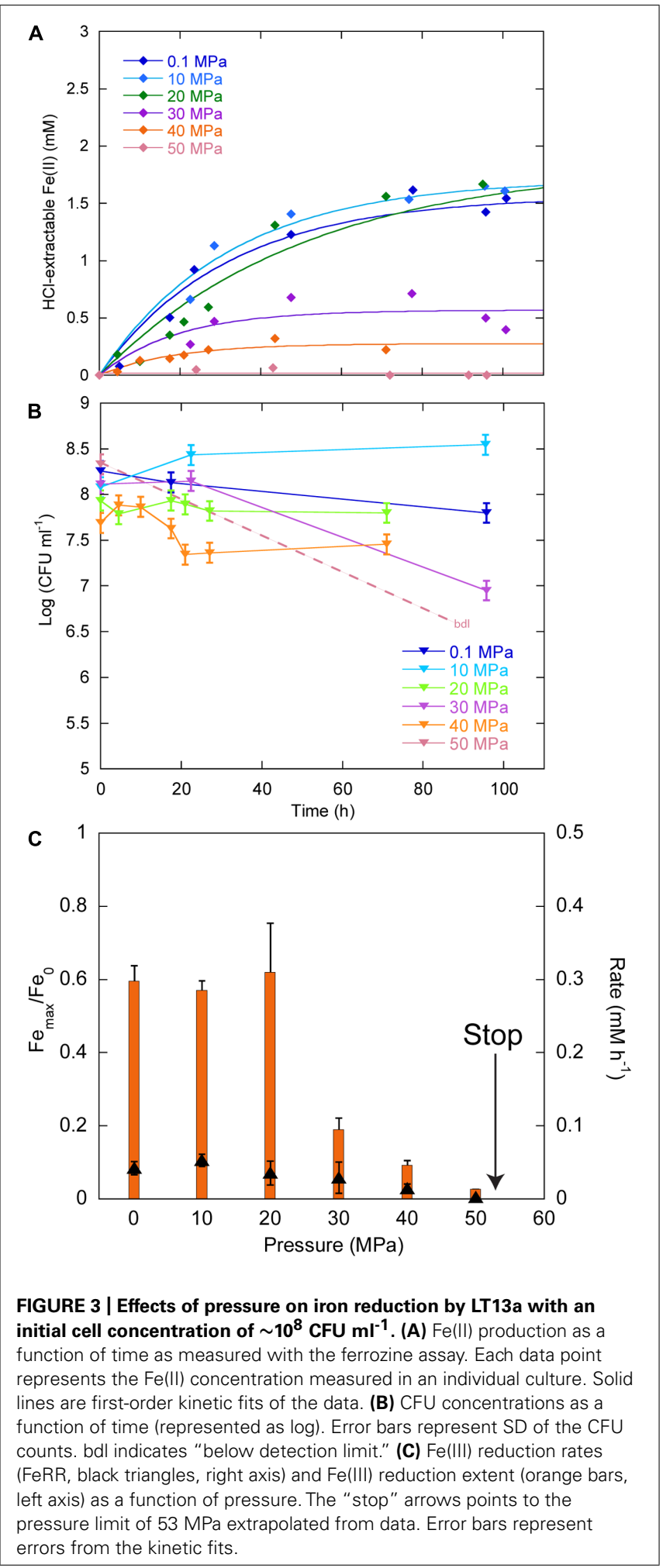

(Roden, 2006). The upper pressure limit for Fe(III) reduction and colony-forming ability appear to be dependent on the initial cell concentration (Figures 3 and 4). At both initial cell concentrations, the arrest of activity is correlated with a loss of viability. The higher pressure limit in experiments starting with $10^{9} \mathrm{CFU} \mathrm{m}{ }^{-1}$
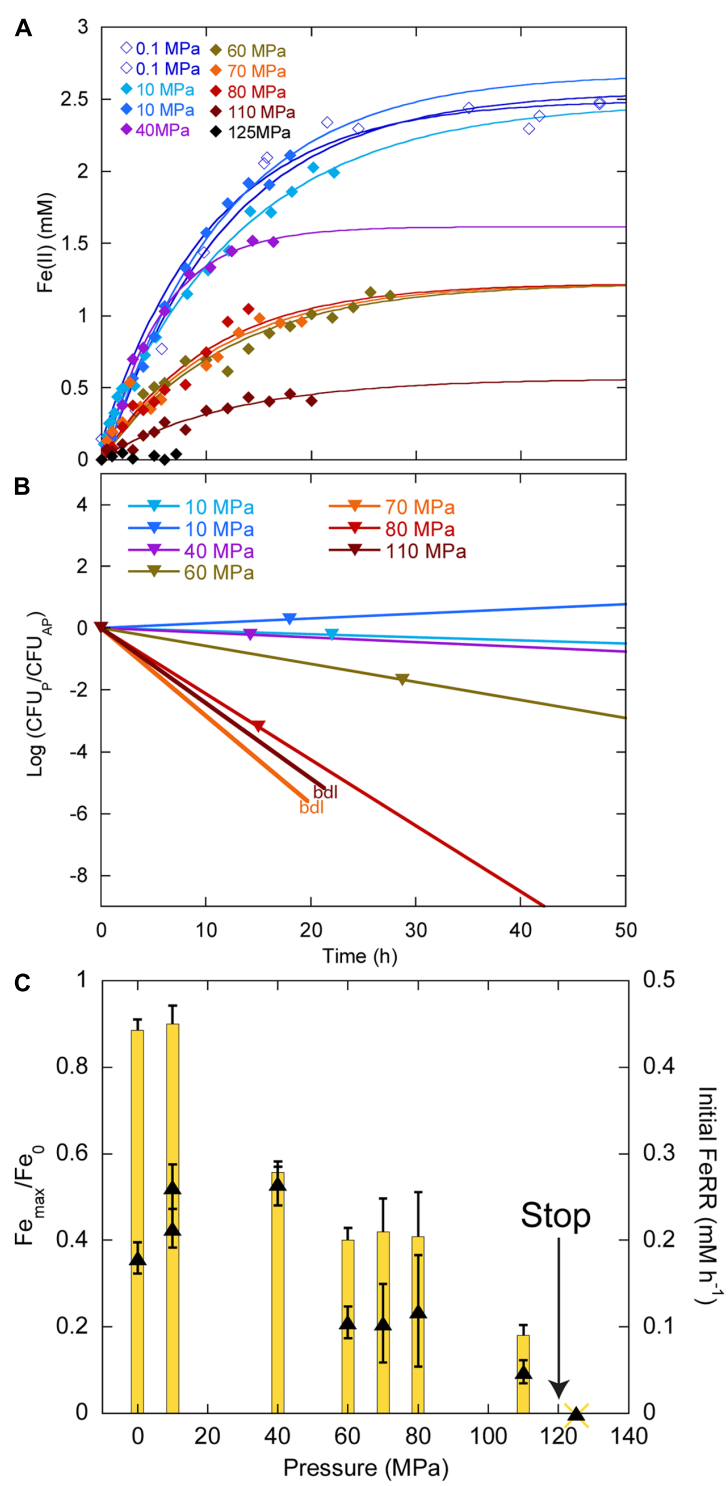

FIGURE 4 | Effects of pressure on iron reduction by LT13a with an

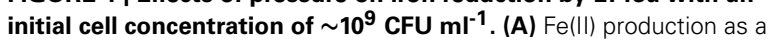
function of time calculated from linear combination fitting analysis of XANES spectra (filled diamonds). Error bars, representing the error on the linear combination fits, are smaller than symbols. Fe(II) measurements at $0.1 \mathrm{MPa}$ were performed EX SITU with the ferrozine assay (open diamonds). Solid lines are first-order kinetic fits of the data. (B) CFU concentrations as a function of time (represented as log of CFU measured at the end of the experiments normalized by the CFU measured at the end of the control experiment at atmospheric pressure, see Materials and Methods). bdl indicates "below detection limit." (C) Fe(III) reduction rates (FeRR, black triangles, right axis) and Fe(III) reduction extent (yellow bars, left axis) as a function of pressure. The "stop" arrows points to the pressure limit of $120 \mathrm{MPa}$ extrapolated from data. Error bars represent errors from the kinetic fits.

could be explained by the fact that more cells are available to reduce $\mathrm{Fe}(\mathrm{III})$ before pressure affects the vitality of cells. This is in good agreement with a previous study investigating the inactivation of Escherichia coli at $100 \mathrm{MPa}$ and $45^{\circ} \mathrm{C}$ with varying initial cell concentration. The inactivation rate of E. coli by pressure decreases 


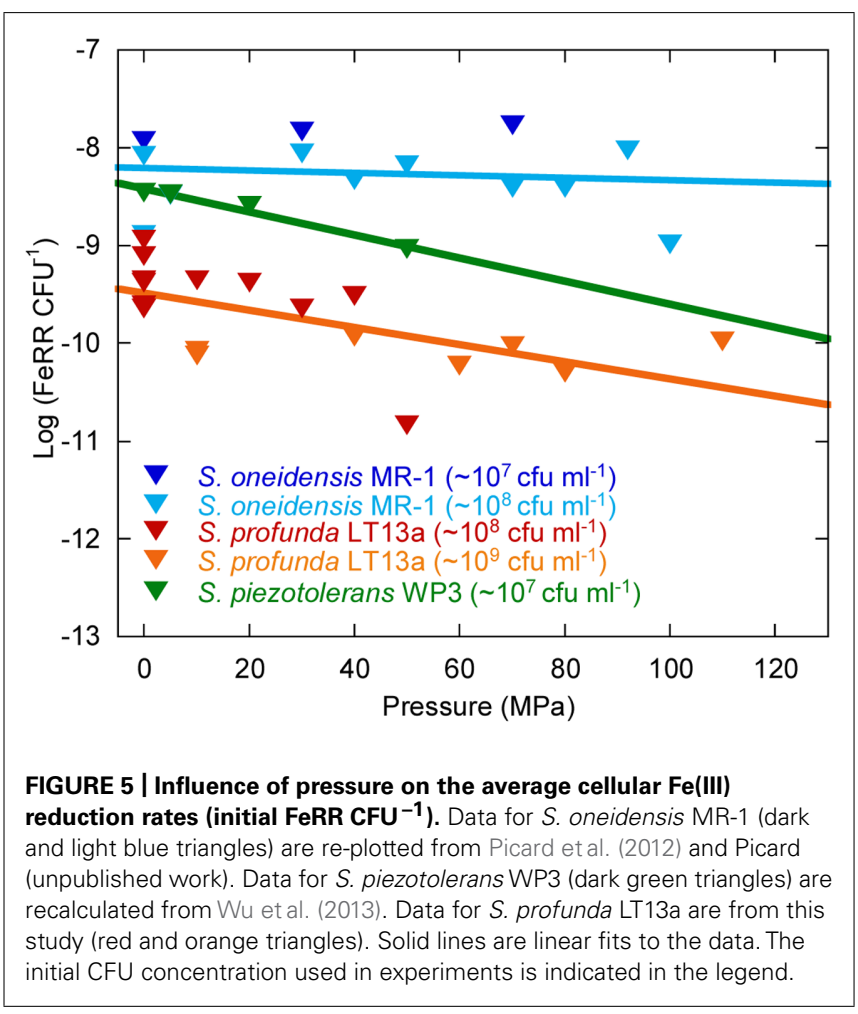

with the increase of initial cell concentration from $10^{4}$ to $10^{9}$ cells $\mathrm{ml}^{-1}$ (Furukawa et al., 2002). One hypothesis to explain this observation is that cells might form aggregates at high cell concentration that are more resistant to pressure than cells alone (Furukawa et al., 2002). The presence of quorum sensing in Shewanella has been suggested by the presence of signaling molecules in several Shewanella species, including marine species and strain MR-1 (Bodor et al., 2008). In Sp LT13a, high CFU concentrations could induce changes in the metabolic state of cells, for example by channeling most energy produced via Fe(III) reduction to cell-maintenancerelated processes, as opposed to growth. The amount of energy used for processes related to growth is higher than that of processes related to cell maintenance or survival (Hoehler and Jorgensen, 2013).

\section{PRESSURE RANGE FOR GROWTH IS NOT INFLUENCED BY CELL DENSITY}

In our experiments, the initial CFU concentrations were similar to those that are reached in stationary phase after an exponential growth phase. Although the metabolic state of cells was certainly different than in an "usual" stationary phase, the observed changes in CFU were similar to those observed in E. coli in a long-term stationary phase (Finkel, 2006). CFU levels were indeed maintained at stable levels at atmospheric pressure, while oscillations occurred, indicating that cells were in a steady-state over the course of the experiments, with a death rate roughly equivalent to the growth rate (Figures $3 \mathrm{~B}$ and $\mathbf{4 B}$ ). Under pressure, CFU were stable up to $40 \mathrm{MPa}$, at both initial cell concentrations, while they decreased quickly above $50 \mathrm{MPa}$, indicating that the death rate rapidly exceeded the growth rate (Figures $3 B$ and $4 B$ ). This is in good agreement with the original description of Sp LT13a that grew up to $50 \mathrm{MPa}$ (Toffin et al., 2004). As a comparison, biosynthetic processes, e.g., cell division or DNA replication, are inhibited in this pressure range in E. coli (Bartlett, 2002).

\section{MECHANISMS OF MICROBIAL ACTIVITY INHIBITION BY PRESSURE}

Upon application of pressure, no delay in $\mathrm{Fe}(\mathrm{II})$ production was observed and initial cellular FeRR only slightly decreased as a function of pressure. This suggests that the respiratory chain was not immediately affected by pressure. This agrees well with the stability of terminal oxidases of respiratory chain that are active up to 200 and $125 \mathrm{MPa}$, respectively, in the piezophilic bacteria S. violacea DSS12 and Photobacterium profundum SS9 (Chikuma et al., 2007; Tamegai et al., 2012). Proteins are stable at least up to pressures of 100-200 MPa (Silva and Weber, 1993). While ATP production is not significantly inhibited in Streptococcus faecalis incubated at $41 \mathrm{MPa}$, the ATP demand increases with increasing pressure (Matsumura and Marquis, 1977). Catabolic processes are generally less sensitive to pressure than anabolic processes (Pope and Berger, 1973). We therefore hypothesize that ATP demand in Sp LT13a might also increase with increasing pressure. That demand could therefore be fulfilled up to $40 \mathrm{MPa}$ as long as growth occurs and a steady-state population is maintained. Above that pressure, only cells in the higher cell density experiments were active. As high cell density might induce a "resting state" for cells which requires less maintenance energy than more active cells, even if levels increase with increasing pressure. Cells would thus be coping with pressure for a longer time, and thus have a higher pressure limit for activity.

\section{ENVIRONMENTAL SIGNIFICANCE OF Shewanella profunda LT13a}

The genus Shewanella is widespread in sedimentary environments and is characterized by a wide metabolic diversity (Kato and Nogi, 2001; Lauro and Bartlett, 2007; Fredrickson et al., 2008). We show here that $S p$ LT13a is potentially active in the range $4-37^{\circ} \mathrm{C}$ and 0.1-120 MPa. In terms of deep environments, this translates into conditions found in the ocean down to the deepest trenches (e.g., Mariana Trench, $11000 \mathrm{~m}$ water depth, $110 \mathrm{MPa}$ ), or in sediments, rocks and aquifers at depths of up to $>1 \mathrm{~km}$ following a normal geothermal gradient. The apparent activation energy of $50.3 \pm 0.8 \mathrm{~kJ} \mathrm{~mol}^{-1}$ at ambient pressure was close to values estimated for $\mathrm{Fe}(\mathrm{III})$ reduction in freshwater environments, i.e., $43.6 \mathrm{~kJ} \mathrm{~mol}^{-1}$ in rhizosphere sediments and $42.3-45.5 \mathrm{~kJ}$ $\mathrm{mol}^{-1}$ in pit lake sediments (Roden and Wetzel, 1996; Meier et al., 2005). The upper pressure limits for Fe(III)-reducing activity of $S$. profunda LT13a and of S. oneidensis MR-1 were similar, 120 and $110 \mathrm{MPa}$ respectively (Picard et al., 2012), even though the first is piezophilic and the second is piezo-sensitive. Only little information about the physiology of Sp LT13a is available (Toffin et al., 2004) and its genome has not been sequenced. However information on S. piezotolerans WP3 could provide some clues about the adaptations of Fe(III)-reducing deep-sea Shewanella strains to deep-sea environments (Wang et al., 2008, 2009; Wu et al., 2013). Strain WP3 reduces Fe(III) at HP (Wu et al., 2013) and average FeRR per CFU follow similar trends as a function of pressure in Sp LT13a and in S. piezotolerans WP3 (Figure 5), suggesting that deep-sea strains might have a similar response 
to pressure. The mtrABC/omcA gene cluster, responsible for metal reduction, is present in WP3 (Wang et al., 2008). Strain WP3 has 55 putative c-type cytochrome genes, suggesting a great metabolic diversity, similarly to MR-1 (Wang et al., 2008). Some of these cytochromes could potentially be adapted to pressure. It appears that MR-1 evolved after WP3 (Wang et al., 2008), explaining why MR-1 has also a wide range of pressure for metabolic activity. Finally strain WP3 increases its levels of low-melting point fatty acids [branch-chained fatty acids (BCFA), monounsaturated fatty acids (MUFA), and eicopentaenoic acid (EPA)] with increasing pressure (Wang et al., 2009). MUFA and BCFA dominate the fatty acid composition of Sp LT13a, however EPA is not produced, at least at atmospheric pressure (Toffin et al., 2004). Deep-sea strains seem thus well adapted to subsurface environments.

Although cell concentrations used in this study are unrealistic for deep subsurface environments, this study reveals some aspects of cell metabolism in conditions where cells might be in a maintenance or "resting" state. In the deep biosphere, microbial cell populations are maintained over geological times, although the biomass turnover is very slow (Colwell and D'Hondt, 2013). Many questions concerning microbial physiological states and energy metabolism in subsurface environments remain unanswered (Hoehler and Jorgensen, 2013). For example, it is still unknown how to distinguish between active and resting cells, or what define maintenance processes in microbial cells. Laboratory studies of subsurface isolates might help to understand better energy regulation and use under in situ pressure and temperature conditions.

\section{ACKNOWLEDGMENTS}

We acknowledge the European Synchrotron Radiation Facility for provision of synchrotron radiation facilities. Aude Picard was funded by MARUM, the Max Planck Society and DFG. This work benefited from the support of the Deep Carbon Observatory.

\section{REFERENCES}

Amann, R. I., Ludwig, W., and Schleifer, K. H. (1995). Phylogenetic identification and in situ detection of individual microbial cells without cultivation. Microbiol. Rev. 59, 143-169.

Bartlett, D. H. (2002). Pressure effects on in vivo microbial processes. Biochim. Biophys Acta 1595, 367-381. doi: 10.1016/S0167-4838(01)00357-0

Bartlett, D. H., Kato, C., and Horikoshi, K. (1995). High pressure influences on gene and protein expression. Res. Microbiol. 146, 697-706. doi: 10.1016/09232508(96)81066-7

Batzke, A., Engelen, B., Sass, H., and Cypionka, H. (2007). Phylogenetic and physiological diversity of cultured deep-biosphere bacteria from Equatorial Pacific Ocean and Peru Margin sediments. Geomicrobiol. J. 24, 261-273. doi: 10.1080/01490450701456453

Biddle, J. F., House, C. H., and Brenchley, J. E. (2006). "Enrichment and cultivation of microorganisms from sediment from the slope of the Peru Trench (ODP site 1230)," in Proceedings of the Ocean Drilling Program, Scientific Results, eds B. B. Jorgensen, S. L. D'hondt, and D. J. Miller (College Station, TX: Ocean Drilling Program), 1-19.

Bodor, A., Elxnat, B., Thiel, V., Schulz, S., and Wagner-Dobler, I. (2008). Potential for luxS related signalling in marine bacteria and production of autoinducer- 2 in the genus Shewanella. BMC Microbiol. 8:13. doi: 10.1186/1471-2180-8-13

Bowles, M. W., Samarkin, V. A., and Joye, S. B. (2011). Improved measurement of microbial activity in deep-sea sediments at in situ pressure and methane concentration. Limnol. Oceanogr. Methods 9, 499-506. doi: 10.4319/lom.2011.9.499

Chikuma, S., Kasahara, R., Kato, C., and Tamegai, H. (2007). Bacterial adaptation to high pressure: a respiratory system in the deep-sea bacterium Shewanella violacea DSS12. FEMS Microbiol. Lett. 267, 108-112. doi: 10.1111/j.15746968.2006.00555.x

Colwell, F. S., and D'Hondt, S. (2013). Nature and extent of the deep biosphere. Rev. Mineral. Geochem. 75, 547-574. doi: 10.2138/rmg.2013.75.17

D’Hondt, S., Jorgensen, B. B., Miller, D. J., Batzke, A., Blake, R., Cragg, B. A., et al. (2004). Distributions of microbial activities in deep subseafloor sediments. Science 306, 2216-2221. doi: 10.1126/science.1101155

DeLong, E. F., and Yayanos, A. A. (1985). Adaptation of the membrane lipids of a deep-sea bacterium to changes in hydrostatic pressure. Science 228, 1101-1103. doi: $10.1126 /$ science. 3992247

Di Giulio, M. (2005). A comparison of proteins from Pyrococcus furiosus and Pyrococcus abyssi: barophily in the physicochemical properties of amino acids and in the genetic code. Gene 346, 1-6. doi: 10.1016/j.gene.2004.10.008

Fang, J., Zhang, L., and Bazylinski, D. A. (2010). Deep-sea piezosphere and piezophiles: geomicrobiology and biogeochemistry. Trends Microbiol. 18, 413422. doi: $10.1016 /$ j.tim.2010.06.006

Finkel, S. E. (2006). Long-term survival during stationary phase: evolution and the GASP phenotype. Nat. Rev. Microbiol. 4, 113-120. doi: 10.1038/nrmicro1340

Fredrickson, J. K., Romine, M. F., Beliaev, A. S., Auchtung, J. M., Driscoll, M. E., Gardner, T. S., et al. (2008). Towards environmental systems biology of Shewanella. Nat. Rev. Microbiol. 6, 592-603. doi: 10.1038/nrmicro1947

Furukawa, S., Noma, S., Shimoda, M., and Hayakawa, I. (2002). Effect of initial concentration of bacterial suspensions on their inactivation by high hydrostatic pressure. Int. J. Food Sci. Technol. 37, 573-577. doi: 10.1046/j.13652621.2002.00586.x

Hoehler, T. M., and Jorgensen, B. B. (2013). Microbial life under extreme energy limitation. Nat. Rev. Microbiol. 11, 83-94. doi: 10.1038/nrmicro2939

Kallmeyer, J., and Boetius, A. (2004). Effects of temperature and pressure on sulfate reduction and anaerobic oxidation of methane in hydrothermal sediments of Guaymas Basin. Appl. Environ. Microbiol. 70, 1231-1233. doi: 10.1128/AEM.70.2.1231-1233.2004

Kato, C., and Nogi, Y. (2001). Correlation between phylogenetic structure and function: examples from deep-sea Shewanella. FEMS Microbiol. Ecol. 35, 223-230. doi: 10.1111/j.1574-6941.2001.tb00807.x

Kostka, J., and Nealson, K. H. (1998). "Isolation, cultivation and characterization of iron- and manganese-reducing bacteria," in Techniques in Microbial Ecology, eds R. S. Burlage, R. Atlas, D. Stahl, G. Geesey, and G. Sayler (New York: Oxford University Press, Inc.), 58-78.

Lauro, F. M., and Bartlett, D. H. (2007). Prokaryotic lifestyles in deep sea habitats. Extremophiles 12, 15-25. doi: 10.1007/s00792-006-0059-5

Lovley, D. R., and Chapelle, F. (1995). Deep subsurface microbial processes. Rev. Geophys. 33, 365-381. doi: 10.1029/95RG01305

Matsumura, P., and Marquis, R. E. (1977). Energetics of streptococcal growth inhibition by hydrostatic pressure. Appl. Environ. Microbiol. 33, 885-892.

Meier, J., Costa, R., Smalla, K., Boehrer, B., and Wendt-Potthoff, K. (2005). Temperature dependence of $\mathrm{Fe}(\mathrm{III})$ and sulfate reduction and its effect on growth and composition of bacterial enrichments from an acidic pit lake neutralization experiment. Geobiology 3, 261-274. doi: 10.1111/j.1472-4669.2006.00065.x

Mikucki, J. A., Liu, Y., Delwiche, M., Colwell, F. S., and Boone, D. R. (2003). Isolation of a methanogen from deep marine sediments that contain methane hydrates, and description of Methanoculleus submarinus, sp. nov. Appl. Environ. Microbiol. 69, 3311-3316. doi: 10.1128/AEM.69.6.3311-3316.2003

Nakasone, K., Ikegami, A., Kato, C., Usami, R., and Horikoshi, K. (1998). Mechanisms of gene expression controlled by pressure in deep-sea microorganisms. Extremophiles 2, 149-154. doi: 10.1007/s007920050054

Parkes, R. J., Sellek, G., Webster, G., Martin, D. D., Anders, E., Weightman, A. J., et al. (2009). Culturable prokaryotic diversity of deep, gas hydrate sediments: first use of a continuous high-pressure, anaerobic, enrichment and isolation system for subseafloor sediments (DeepIsoBUG). Environ. Microbiol. 11, 3140-3153. doi: 10.1111/j.1462-2920.2009.02018.x

Picard, A., and Daniel, I. (2013). Pressure as an environmental parameter for microbial life - A review. Biophys. Chem. 183, 30-41. doi: 10.1016/j.bpc.2013.06.019

Picard, A., Daniel, I., Testemale, D., Kieffer, I., Bleuet, P., Cardon, H., et al. (2011). Monitoring microbial redox transformations of metal and metalloid elements under high pressure using in situ X-ray absorption spectroscopy. Geobiology 9 , 196-204. doi: 10.1111/j.1472-4669.2010.00270.x

Picard, A., Testemale, D., Hazemann, J. L., and Daniel, I. (2012). The influence of high hydrostatic pressure on bacterial dissimilatory iron reduction. Geochim. Cosmochim. Acta 88, 120-129. doi: 10.1016/j.gca.2012.04.030 
Pope, D. H., and Berger, L. R. (1973). Inhibition of metabolism by hydrostatic pressure: what limits microbial growth? Arch. Mikrobiol. 93, 367-370. doi: 10.1007/BF00427933

Proux, O., Biquard, X., Lahera, E., Menthonnex, J.-J., Prat, A., Ulrich, O., etal. (2005). FAME: a new beamline for $\mathrm{x}$-ray absorption investigations of very-diluted systems of environmental, material and biological interests. Phys. Scr. 115, 970-973. doi: 10.1238/Physica.Topical.115a 00970

Proux, O., Nassif, V., Prat, A., Ulrich, O., Lahera, E., Biquard, X., et al. (2006). Feedback system of a liquid-nitrogen-cooled double-crystal monochromator: design and performances. J. Synchrotron Radiat. 13, 59-68. doi: 10.1107/S0909049505037441

Ravel, B., and Newville, M. (2005). ATHENA, ARTEMIS, HEPHAESTUS: data analysis for X-ray absorption spectroscopy using IFEFFIT. J. Synchrotron Radiat 12, 537-541. doi: 10.1107/S0909049505012719

Roden, E. E. (2006). Geochemical and microbiological controls on dissimilatory iron reduction. C. R. Geosci. 338, 456-467. doi: 10.1016/j.crte.2006. 04.009

Roden, E. E., and Wetzel, R. G. (1996). Organic carbon oxidation and suppression of methane production by microbial $\mathrm{Fe}$ (III) oxide reduction in vegetated and unvegetated freshwater wetland sediments. Limnol. Oceanogr. 41, 1733-1748. doi: 10.4319/lo.1996.41.8.1733

Roden, E. E., and Zachara, J. M. (1996). Microbial reduction of crystalline iron(III) oxides: influence of oxide surface area and potential for cell growth. Environ. Sci Technol. 30, 1618-1628. doi: 10.1021/es9506216

Silva, J., and Weber, G. (1993). Pressure stability of proteins. Ann. Rev. Phys. Chem. 44, 89-113. doi: 10.1146/annurev.pc.44.100193. 000513

Simonato, F., Campanaro, S., Lauro, F. M., Vezzi, A., D’angelo, M., Vitulo, N., et al. (2006). Piezophilic adaptation: a genomic point of view. J. Biotechnol. 126, 11-25. doi: 10.1016/j.jbiotec.2006.03.038

Stookey, L. L. (1970). Ferrozine - A new spectrophotometric reagent for iron. Anal. Chem. 42, 779-781. doi: 10.1021/ac60289a016

Tamegai, H., Nishikawa, S., Haga, M., and Bartlett, D. H. (2012). The respiratory system of the piezophile Photobacterium profundum SS9 grown under various pressures. Biosci. Biotechnol. Biochem. 76, 1506-1510. doi: 10.1271/bbb.1 20237

Testemale, D., Argoud, R., Geaymond, O., and Hazemann, J.-L. (2005). High pressure/high temperature cell for $\mathrm{x}$-ray absorption and scattering techniques. Rev. Sci. Instrum. 76:043905. doi: 10.1063/1.1884188

Toffin, L., Bidault, A., Pignet, P., Tindall, B. J., Slobodkin, A., Kato, C., et al. (2004). Shewanella profunda sp. nov., isolated from deep marine sediment of the Nankai Trough. Int. J. Syst. Bacteriol. 54, 1943-1949. doi: 10.1099/ijs.0.0 3007-0
Venkateswaran, K., Moser, D. P., Dollhopf, M. E., Lies, D. P., Saffarini, D. A., Macgregor, B. J., et al. (1999). Polyphasic taxonomy of the genus Shewanella and description of Shewanella oneidensis sp. nov. Int. J. Syst. Bacteriol. 49, 705-724. doi: 10.1099/00207713-49-2-705

Vossmeyer, A., Deusner, C., Kato, C., Inagaki, F., and Ferdelman, T. G. (2012). Substrate-specific pressure-dependence of microbial sulfate reduction in deepsea cold seep sediments of the Japan Trench. Front. Microbiol. 3:253. doi: 10.3389/fmicb.2012.00253

Wang, F., Wang, J., Jian, H., Zhang, B., Li, S., Wang, F., et al. (2008). Environmental adaptation: genomic analysis of the piezotolerant and psychrotolerant deep-sea iron reducing bacterium Shewanella piezotolerans WP3. PLoS ONE 3:e1937. doi: 10.1371/journal.pone.0001937

Wang, F., Xiao, X., Ou, H. Y., and Gai, Y. (2009). Role and regulation of fatty acid biosynthesis in the response of Shewanella piezotolerans WP3 to different temperatures and pressures. J. Bacteriol. 191, 2574-2584. doi: 10.1128/JB.00 498-08

Wu, W. F., Wang, F. P., Li, J. H., Yang, X. W., Xiao, X., and Pan, Y. X. (2013). Iron reduction and mineralization of deep-sea iron reducing bacterium Shewanella piezotolerans WP3 at elevated hydrostatic pressures. Geobiology 11, 593-601. doi: $10.1111 /$ gbi.12061

Yayanos, A. A. (1995). Microbiology to 10,500 meters in the deep sea. Annu. Rev. Microbiol. 49, 777-805. doi: 10.1146/annurev.mi.49.100195.004021

Zobell, C. E., and Oppenheimer, C. H. (1950). Some effects of hydrostatic pressure on the multiplication and morphology of marine bacteria. J. Bacteriol. 60, $771-781$.

Conflict of Interest Statement: The authors declare that the research was conducted in the absence of any commercial or financial relationships that could be construed as a potential conflict of interest.

Received: 01 August 2014; accepted: 25 December 2014; published online: 21 January 2015.

Citation: Picard A, Testemale D, Wagenknecht L, Hazael $R$ and Daniel I (2015) Iron reduction by the deep-sea bacterium Shewanella profunda LT13a under subsurface pressure and temperature conditions. Front. Microbiol. 5:796. doi: 10.3389/fmicb.2014.00796

This article was submitted to Extreme Microbiology, a section of the journal Frontiers in Microbiology.

Copyright (c) 2015 Picard, Testemale, Wagenknecht, Hazael and Daniel. This is an open-access article distributed under the terms of the Creative Commons Attribution License (CC BY). The use, distribution or reproduction in other forums is permitted, provided the original author(s) or licensor are credited and that the original publication in this journal is cited, in accordance with accepted academic practice. No use, distribution or reproduction is permitted which does not comply with these terms. 